\title{
Free-Water Intake as a Measure of Total Body Water in Cattle
}

\author{
M.K. Shebaita and A. Prau * \\ Depaitment of Animal Science, Faculty of Agriculture at \\ El-Fayoum, El-Fayoum, Egypt.
}

\begin{abstract}
QIX mature Friesian bulls at average body weight of $562 \mathrm{~kg}$ were 1. injected with ${ }^{3} \mathrm{HOH}$ under ambient temperature of $16^{\circ}$ and $60 \%$ RH to compare between total body water estimated by extrapolation method either from bleod or urine samples and equilibration method from blood samples. A total of 12 blond samples were taken during the period of 2-192 hr post injection. Urine was daily collected at 24-192 hr post injection. Free-water intake was daily measured for 8 days.

The data showed that there was no significant difference in total body water determined from blood $(24-192 \mathrm{hr})$ or from urine (24-192 hr) samples by applying the extrapolation method. However, significant differences $(\mathrm{P}<0.05)$ were observed in biological halfife and water turnover rate. Insignificant differences in total body watel either estimated fiom one wood sample taking at 2 or $4 \mathrm{hr}$ post injection (equilibration method) and extrapolation method. Therefore, after $2 \mathrm{hr}$ post injection with " $\mathrm{HOH}$, the values of tota! body water and in-vivo body composition ( prctein, fat and ash) could be obtained instead of waiting 8 days to obtain these information.

Free-water intake was found to be significantly $(\mathrm{P}<0.01)$ correlated with total body water and water turnover rate. The predicted equations were: 1) Total body water, $I=427.2-1.1519$ Free - water intake, 1 and 2) Water turnover rate, $1 /$ day $-23.2+0.219$ Free-water intake, 1. Therefore, it is possible to predict watet turnover rate, biological half-life, total body water and in-vivo body composition from meacuring water intake instead of injecting radioactive material. This would help to measure the daily variation in the abovementioned parameters
\end{abstract}

Radioactive water ( ${ }^{3} \mathrm{HOH}$ ) has been commonly used to determine total body water, body composition and water turnover rate (Shebaita et al., 1973, 1975; Pfau and Shebaita, 1980; Shebaita and Elbanna, 1982) by applying the extrapolation method $\left(A_{t}=A_{0}, c-A t\right)$ from blood samples. Many attempts (Macfarlane et al., 1966, 1974) have been made by equilibration method to determine total body water by taking only one blood or urine sample after equilibraicn $(6 \mathrm{hr})$ Although, Pfau and Salem (1972) stated that the extrapolation method is more reliable than equilibration method when ${ }^{3} \mathrm{HOH}$ is determined in blood. On the other hand, the close value between water turnover rate and water consumption (El-Fouly et al., 1979; Shebaita and Elbanna, 1982) provides 
promising basis for predicting water intake under grazing conditions or when water consumption cannot be recorded. If such relation holds to be true, therefore, it is possible to predict water turnover rate, total body water and invivo body composition from measuring water intake instead of injecting radioactive material and consequently increasing contamination. The abovementioned information were the bases for this studv.

\section{Material and Methods}

Six mature Friesian bulls at average body weight of $562 \mathrm{~kg}$ were maintaine 1 in controlled climatic barn at $16^{\circ}$ and $60 \% \mathrm{RH}$. The bulls were prevented from feed and water for $12 \mathrm{hr}$ before the injection with ${ }^{3} \mathrm{HOH}$ as explained by pfau and Shebaita (1980). Blood samples were collected at 2,4,6,12,24 hr. and every $24 \mathrm{hr}$ up to $192 \mathrm{hr}$ ( 8 days) post injection. Free-water intake and total urine output were measured every $24 \mathrm{hr}$ for 8 days. The counting procedure of radioactive material in serum water or in urine water was done as explained before (Pfau and Shebaita, 1980).

\section{Results and Discussion}

Table I shows the values of total body water, biological halflife and water turnover rate using the extrapolation method either from serum water or from urine water. The data showed insignificant difference in calculating total body water whether the counting samples were from serum or urine using the extrapolation method (24-192 hr) as shown in Table 2. However, biological half-life was significantly $(\mathrm{P}<0.05)$ higher and water turnover rate was significantly lower $(\mathrm{P}<0.05)$ from urine samples compared with serum samples. These finding are in agreement with Macfarlane et al. (1974) who pointed out that once equilibration has occurred there is theoretically no difference between the ratio of radioactive hydrogens to the hydrogen molecules in any body fluid. Plasma water, red cell water, tissue fluid, urine or fecal water, tears or milk,respiratory water or sweat should all contain the same ratio. This is not, however, quite strictly true since it is difficult to get a uniform sample of urine when the bladder accumulates different concentraions over the course of some hours. The most useful samples are that taken from blood and both cells and plasma may be used to provide the water for measurement.

It is worthnoting, however, that there were no significant differences in total body water,biological half-life and water turnover rate for the different sampling times from the blood (Tables 1 and 2). Nevertheless, extrapolation method using the whole collected samples $(2-192 \mathrm{hr})$ is recommended because it gives the closest true value of the instantaneous picture of the ratio between radioactive hydrogens and the hydrogen molecules in the body fluid.

Comparison between total body water in Friesian bulls by the equilibration and that estimated by extrapolation method $(2-192 \mathrm{hr})$ are shown in Table 3. Generally, total body water determined by the requilibration at 2 and $4 \mathrm{hr}$ were $4.03 \%$ and $1.88 \%$, respectively less than that obtained from the extrapolation method. The values determined by equilibration at 6.12 and $24 \mathrm{hr}$ were $5.29-9.07 \%$ higher than that obtained from extrapolation method (Table 3).

Egypt. I Anim. Prod. 23, No. 1 - 2 (1983) 
TABLE 1. Total body water (TBW, I.), hiological half-life ( $\mathbf{B}_{\frac{1}{3}}$, hr.) and water turnover rate (WTR, 1./day) using extrapolation method.

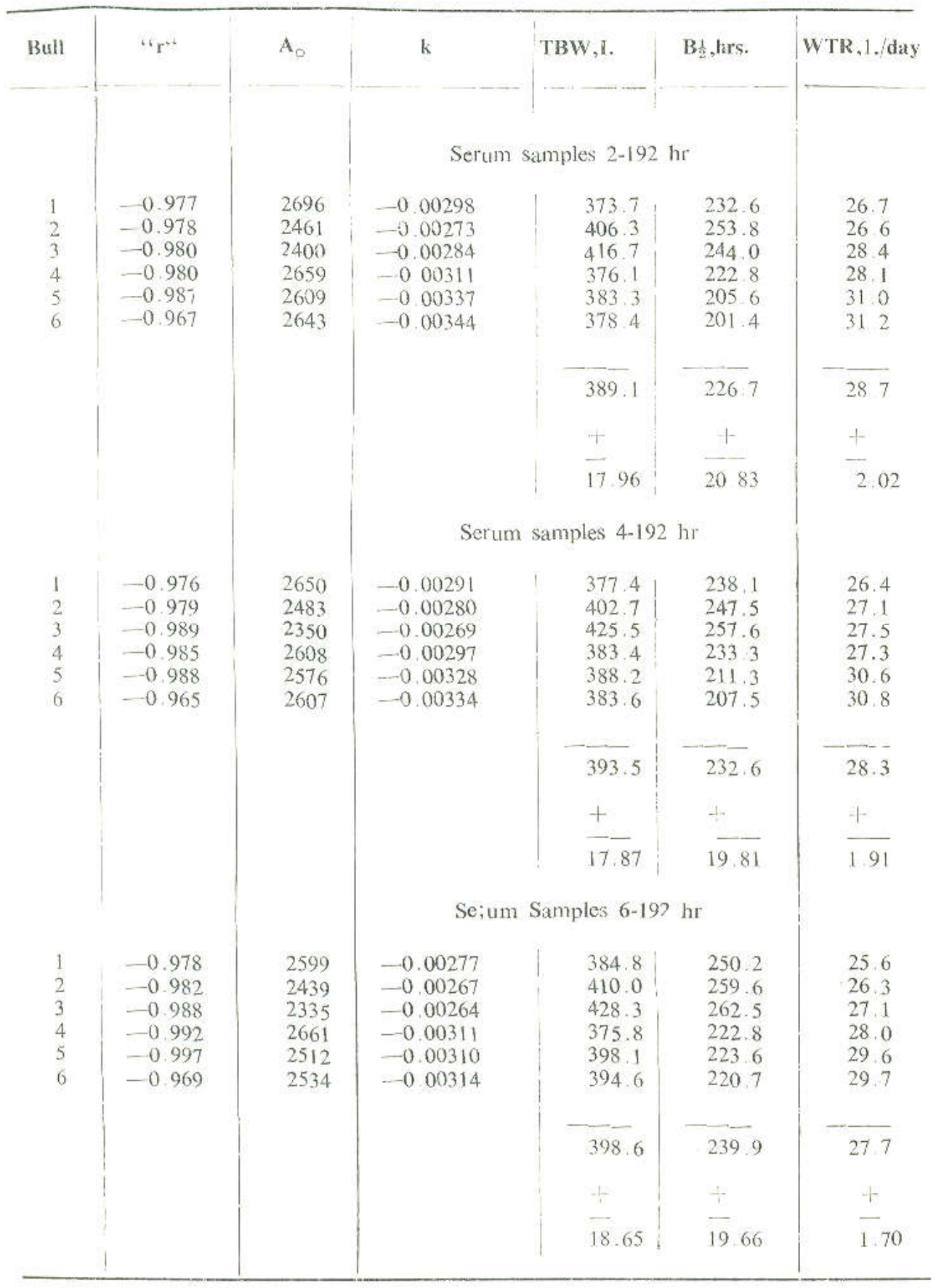

Egypt. J Anim. Prod. 23, No. 1-2 (1983) 
TABLE 1. (COMT).

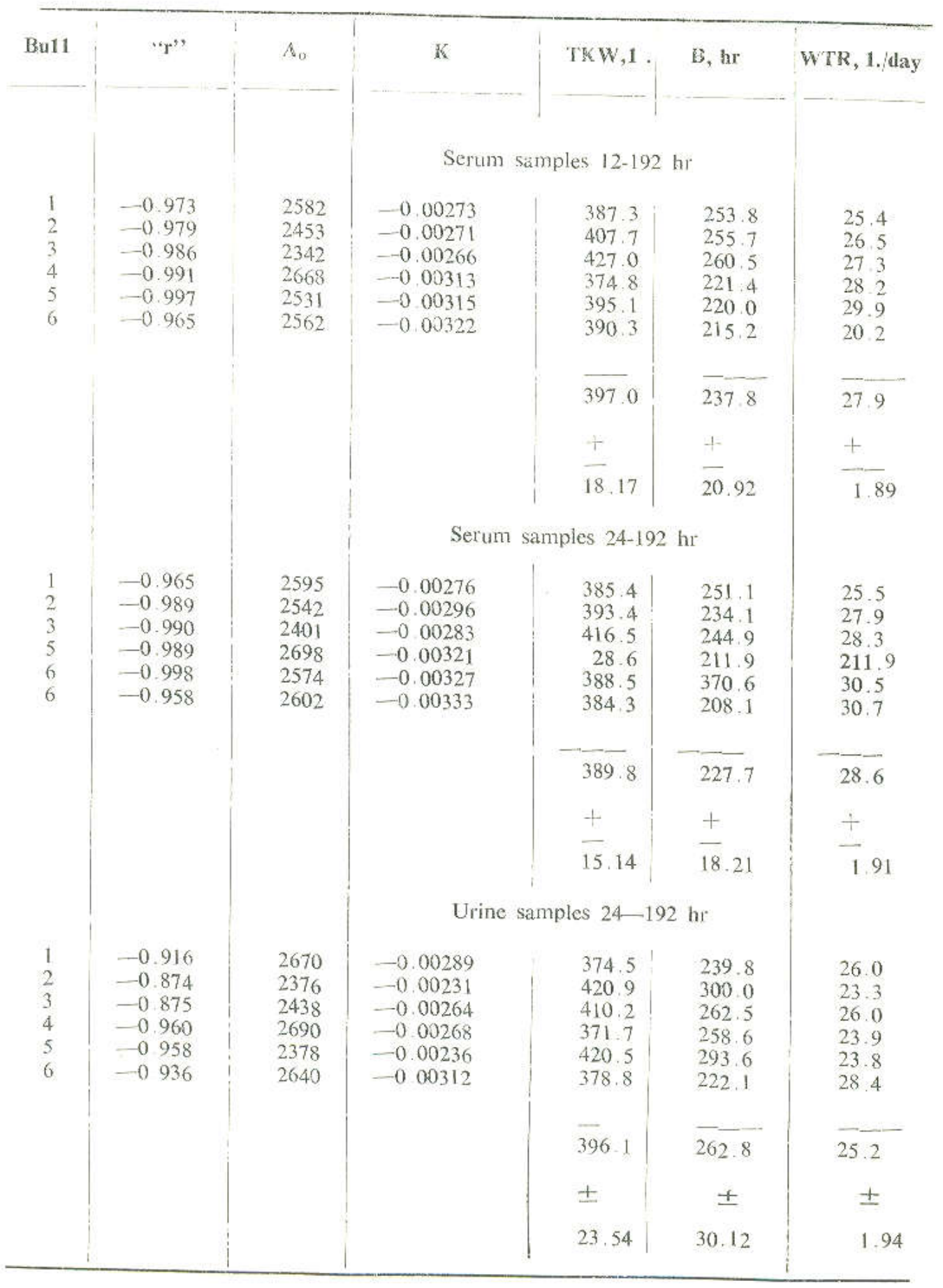

Egypt. I. Anim. Prod. 23, No. 1 - 2 (1983) 
TABLE 2. Test ơ significance.

\begin{tabular}{|c|c|c|c|c|c|c|c|c|}
\hline & Item & & & & & TBW & $B \frac{1}{3}$ & WTK \\
\hline Serum 2-192 & $\times 4-192$ & & & & $\therefore$ & NS & NS & NS \\
\hline Serum 2-192 & $\times 6-192 \ldots$ & . . & & & $\cdot$ & NS & NS & NS \\
\hline Serum $2-192$ & $\times 12-192$ & & & & & NS & NS & NS \\
\hline Serum 2-192 & $\times 24-192 \ldots$ & . & & & 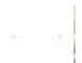 & NS & NS & NS \\
\hline Serum $2-192$ & $\times$ urine $24-192$ & & & & $\cdots$ & NS & $<0.05$ & $<005$ \\
\hline Serum 4-192 & $\times 6-192$ & & & & . & NS & NS & NS \\
\hline Serum 4-192 & $\times 12-192$ & & & $\therefore$ & $+\cdots$ & NS & NS & NS \\
\hline Serum 4-192 & $\times 24-192 \ldots$ & & & & $\cdots$ & NS & NS & NS \\
\hline Serum 4-192 & $x$ urine $24-192$ & . . & $\cdots$ & & $\cdots$ & NS & $<0.10$ & $<0.10$ \\
\hline Serum $6-192$ & $\times 12-192$ & & & & $\cdot$ & NS & NS & NS \\
\hline Serum 6-192 & $\times 24-192 \ldots$ & & & & & NS & NS & NS \\
\hline Serum $6-192$ & $\times$ urine $24-192$ & $\therefore$ & $\cdots$ & . & $\cdots$ & NS & NS & $<0.05$ \\
\hline Serum $12-192$ & $\times 24-192$ & & & $\therefore$ & $\cdots$ & NS & NS & NS \\
\hline Serum $12-192$ & $\times$ urine $24-192$ & 2. . & . . & & $\therefore$ & NS & NS & $<0.05$ \\
\hline Serum $24-192$ & $\times$ urine $24-192$ & 2. & . & . &.. & NS & $<0.05$ & $<0.05$ \\
\hline
\end{tabular}

NS not significant

The insignificant lower total body water values by equilibration at 2 and $4 \mathrm{hr}$ compared with the extrapolation is due to the fact that tritiated water $\left({ }^{3} \mathrm{HOH}\right)$ takes at least $6 \mathrm{hr}$ to equilibrate with rumen water (Till and Downes, 1962; Kamal and Seif, 1969 and Macfarlane et al., 1974). However, equilibration at 2 and $4 \mathrm{hr}$ in this study measure about $96-98 \%$ of the total body water. In this respect, Macfarlane et al. (1969), Searle (1970) and Kamal (1979) found that sampling $1-4 \mathrm{hr}$ after dosing permits to measure about $96-98 \%$ of the total body water in cattle, sheep and goats, including their rumen water. On the contrary, El-Fouly et al, (1979) found a uniform distribution of ${ }^{3} \mathrm{HOH}$ activity in blood and ruminal water sub-pools was noticed approximately $12-18 \mathrm{hr}$ after injection. Also ${ }^{3} \mathrm{HOH}$ specific activity in the rumen reached $90-95 \%$ of that in the blood at $8 \mathrm{hr}$ post injection. While Macfarlane (1965) and Macfarlane and Howard (1966) used a $6 \mathrm{hr}$ sample to calculate total body water, Macfarlane et al. (1967) used one $24 \mathrm{hr}$ sample for such calculation.

It is admitted, however, that the extrapolation method yields a true total body water from a biodecay curve. Besides, it gives the possibility of computing water turnover rate and biological half-life Equilibration method has more advantage for not depriving the animals from feed and water for 6-8 hr.

Egypt. J. Anim. Prod. 23, No. 1-2 (1983) 
especially under hot climate. So the animals do not lose water by vaporization during such a time ( 2 or $4 \mathrm{hr}$ ). Moreover, the disadvantage of radioactive hydrogen exchango with tissue hydrogen and the physiological systems in the body are not disturbed by such a measurement. Above all, after 2-4 $\mathrm{hr}$ post injection, the value of total body water and consequently the in-vivo body composition could be obtained instead of waiting at least 8 days to obain these information.

TABLE 3. Total body water using equilibration method.

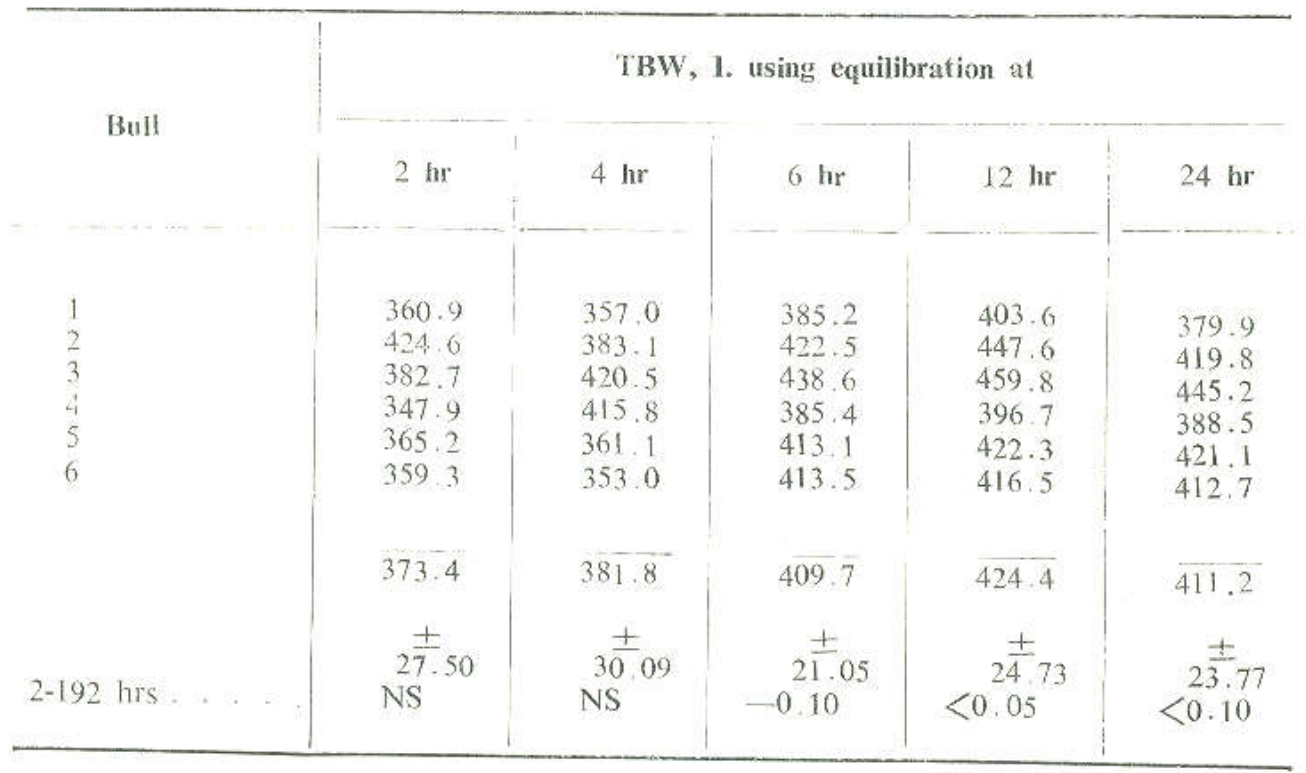

NS not significant

Table 4 shows the averages of free-water intake for each bull. Simple linear relationships between free-water intake and either total body water or water turnover rate using extrapolation method (2-192hr.) were found to be significant $(\mathrm{P}<0.01)$. The comparison between free-water intake and water turnover rate have been studied by many investigators and found that water turnover rate is similar to water consumption in cattle, sheep and goats (Macfatlene et al., 1974; Fl-Fouly et al., 1979; Shebaita and Elbanna, 1982).

Unfortunately, no data are available on the relationship between freewater intake and total body water for comparison. However, this relationship should be exist. In this respect, Strauss (1957) has shown that thirst could be stimulated by many factors such as extracellular fluid deficiency, concentration of the intracellular body fluid, body water deficit and/or the hypertonicity of the extracellular fluid. However, most of these factors though different in nature still prove that thirst is stimulated through one main factor, which is the decrease in total body water content.

Egypt. J. Anim. Prod. 23, No. 1 - 2 (1983) 
It is advisable to test the relaionship between water intake and total body water under different circumstances. If such relation holds to be true, therefore, it is possible to predict water turnover rate, biological half-life, total body water and in-vivo body composition from measuring water intake instead of injecting radioactive material. This would help to measure the daily variation in the above mentioned parameters.

TABLE 4. Frec-water intake, I. and prediction equations.

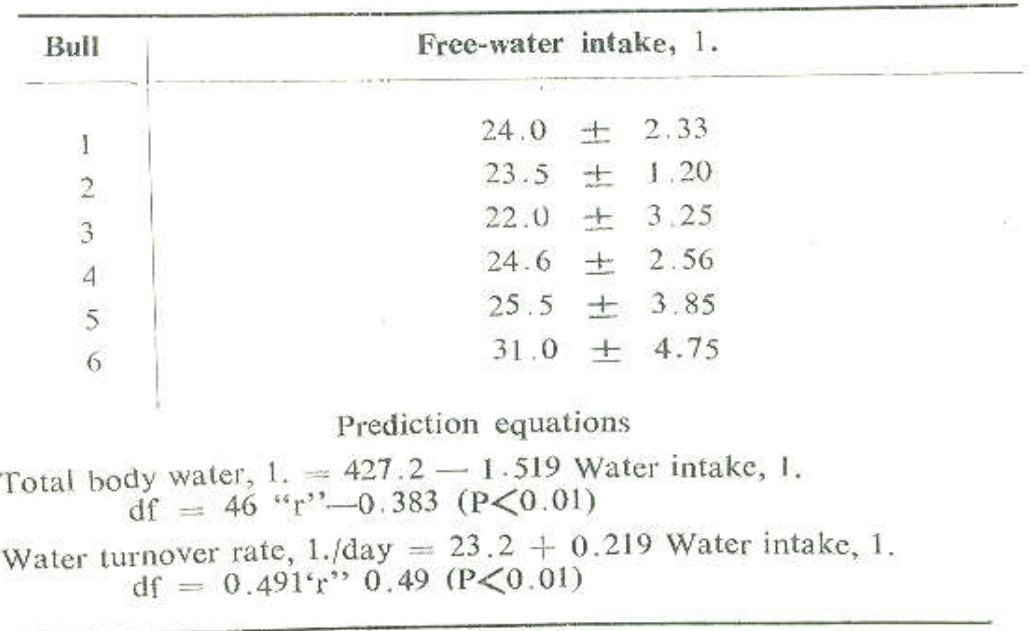

\section{Ref erences}

El-Fouly, H.A., Elbanna, I.M. and Kamal, T.H. (1979) Estimation of equilibrium time between rumen and blood water using a modified TOH extraction technique in sheep. Arab. $J$. Nucl. Sci. \& Appl. 12, 593 ,

Kamal, T.H. (1979) The effect of watering system on water turnover rate and body water and the prediction of summer growth rate in farm animals using the tritiated water dilution technique. Paper presented at 4 th FAO/IAEA research coordination meeting on Water requirement of tropical herbivores based on measurement with tritiated water. Nairobi, Kenya .

Kamal, T.H. and Seif, S.M. (1969) Effect of natural and controlled climates of the Sahara on virtual tritium space in Friesians and water Buffaloes. J. Dairy Sci. 521657 -.

Macfarlane, W.V. (1965) Water metabolism of desert ruminants. Studies in Physiology, SpringerVerlag, $191-199$.

Macfarlane, W.V. (1966) Howard, B., Water content and turnover of identical twin Bos indicus and B. taurus in Kenya. I. Agric. Sic. 66,297- .

Macfarlane, W.V. Howard, B. and Good, B.F. (1974) Tracers in field measurements of water, milk and thyroxine metabolism of tropical ruminants. In Trac. Tech. Trop. Anim. Prod., FAO/TAEA Pub. 1-23.

Macfarlane, W.V., Howard, B., Morrison, J.F., and Wyndham, C.H. (1966) Content and turnover of water in bantu miners acclimatizing to humid heat. J. Appl. Physiol. 21, 978.

Macfarlane, W.V., Howard, B.and Siebert, B.D. (1969) Tritiated water used to measure intake. of milk and tissue growth of ruminants in the field. Nature 221, 578.

Macfarlane, W.V., Howard, B. and Siebert, B.D. (1967) Water metabolism of merino and border leicester sheep grazing saitbush. Aust. J. Agric. Res. 18, 947.

$$
\text { Egypt. J. Anim. Prod. 23, No. 1-2 (1983) }
$$


Pfau, A., and Salem, M.A.I. (1972) Studies on body composition of cattle by isotope dilution analysis. In /sot. Stu. Physiol. Domest. Anin., FAO/LAEA Pbu. 21-33 .

Pfau, A. and Shebaita, M.K. (1980) Studies on bodu water in bulls under heat stress. Pape. presented at 31 th Meeting of Europ. Soc. Anim. Prod. Munich.

Searle, T.W., (1970) Body composition in lambs and young sheep and its prediction in-vivo from tritiated water space and body weight. J. Agric. Sci. 74, 357.

Shebaita, M.K., Elbanna, I.M., Heat load and heat dissipation in sheep and goats under environmental heat stress. Zoot. Res. (In Press).

Shebaita, M.K., El-Fouly, H.A.,and Abou-Akkada, A.R. (1975) Effect of synthetic estrogen on body compartments. Wid. Rev. Anim. Prod. 11 44- .

Shebika, M.K., Seif, S.M.,and Kamal, T.H.(1973)In-vivo body composition in ruminants: 2-New equation for lean body mass. Alex. J. Agric. Res. 21 351-360. .

Strauss, M.B. (1957) Body Water in Man, 1st edn., Brown \& Company, Boston-Toronto, Till, A.R., Downes, A.M. (1962) The measurement of total body water in the sheep. Aust. J. Agric. Res. 13, 335.
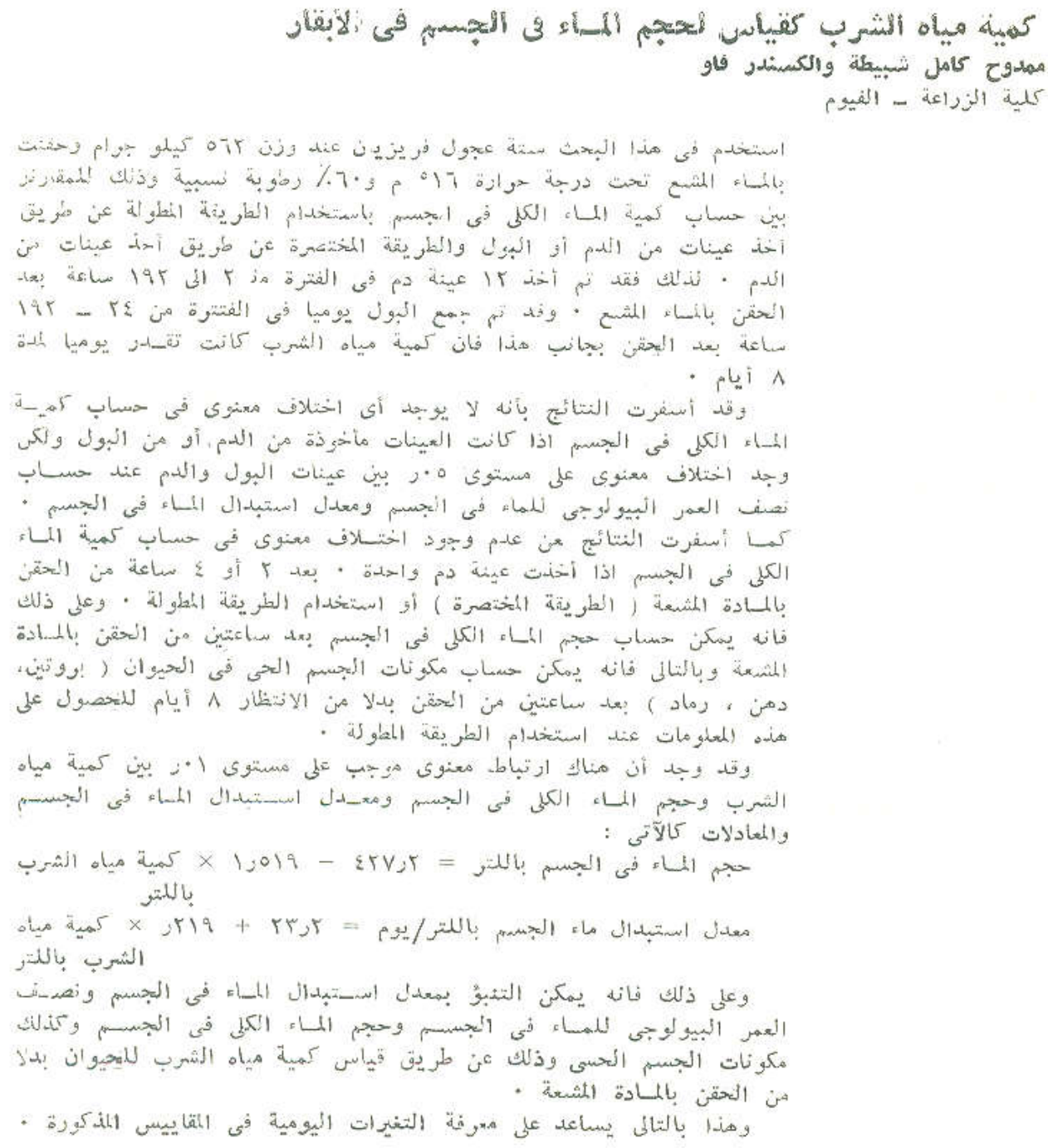